\title{
Investigation of interaction between acoustic field and nonhomogeneous building structures
}

\author{
R. Mikalauskas*, V. Volkovas** \\ *Kaunas University of Technology, Technological System Diagnostic Institute, Kęstučio str. 27, 44312 Kaunas, Lithuania, \\ E-mail: robertas.mikalauskas@ktu.lt \\ **Kaunas University of Technology, Technological System Diagnostic Institute, Kęstučio str. 27, 44312 Kaunas, \\ Lithuania,E-mail: vitalijus.volkovas@ktu.lt
}

crossref http://dx.doi.org/10.5755/j01.mech.17.3.504

\section{Introduction}

Recently, acoustic properties of various structure systems of the buildings concerning noise reduction are becoming the major field of investigation among scientists, designers and manufacturers. The reasons of noise, which is propagating in the air and structural medium of the rooms, are human activities, sound expression of human emotions, and processes of the technical machinery systems. Control of these processes to reduce the noise is usually very complicated and sometimes impossible. That's why this problem is usually solved by using passive noise damping systems which are based on sound wave absorption, diffraction and throughput losses, and reduction of oscillations. Recent years show the growth of unique buildings for industry, leisure and sports, and the need of prediction of structural system behaviour subjected to acoustic load is becoming more and more important to effectively reduce noise inside the building as well as outside during design, construction and exploitation. To be able to predict the interaction between building structure systems [1-3] and acoustic field, modelling of closed space structure (wall, ceiling, flooring, partition walls) geometry and physical properties influence on noise (sound) parameters under acoustic load at given space point is performed. The investigation of such influence can be done by applying both mathematical and physical modelling, which can be realized by analytical method or applying numerical methods. Evaluating different physical and mechanical properties of the closed space structure (walls, ceilings, flooring, partition walls) of the building, including possible damages, the latter can be considered as non-homogeneous.

Existing empirical [4], simplified analytic [5, 6] and numerical [7-9] sound propagation models, do not allow to accurately identify not only the field created by the sound source at the particular point of the real space, but also to quality identify the influence of the structure of noise reduction means and acoustic properties on the sound pressure level at particular point. Due to these problems wider application of numerical experiments is limited. Physical modelling also has its limits - sound pressure isoline picture has to be created. This process requires a lot of time and technical resources, and prevents from fast response to changing technical environment.

To effectively reduce noise in the buildings, acoustic field models, which depend on closed space properties $[7,8,10]$, are needed. The latter have influence on field parameters and its distribution in the investigated space $[5,9]$.

The analysis shows there are no mathematical models which would allow using numerical methods researching physical properties, geometry, and condition change of the building structure influence on acoustic noise at particular space point and real conditions, and particular nonhomogeneity.

With the help of acoustic field 2D and 3D models created in this work, the interaction between acoustic field and non-homogeneous structure using real exploitation conditions and condition of the structure (for example mechanical defect of the system) will be investigated.

\section{FEM based models for acoustic field and building structure}

Two models of acoustic field interaction with the structure have been created and investigated. First model two dimensional. Interaction between partition wall and acoustical medium has been modelled (given different conditions of the partition wall). Second model - three dimensional model, which is used to analyze two floorcolumn structure, using acoustic and mechanical excitation and different nonhomogeneity degrees of the structure. Possible mechanical system defect - reduction of rigidity due to floor flaw, has been modelled during the second modelling. In both models the meshing was chosen according to the rule of six elements per wavelength. The ANSYS 10 software package has been used for both models.

\subsection{Interaction between partition wall and acoustic field 2D model}

The researched two dimensional model consisted of acoustic and structural mediums. FLUID29 and PLANE42 elements have been used for the modelling. Harmonic analysis has been performed during modelling. During the analysis the system has been harmonically excited applying sound pressure of particular magnitude and concentrated horizontal force at the top point of the partition wall with the resonance frequency of the partition wall. The condition of the acoustic partition wall has been altered during analysis, i.e., gypsum wallboard without defect and with flaw defect was modelled. The partition wall defect has been modelled altering its rigidity while bending, by forming a horizontal crack of $2.5 \mathrm{~cm}$ at the middle of partition. The distance between the source of excitation and the partition wall was $1 \mathrm{~m}$. Physical properties of the model components were the following: air density $\rho=1.2 \mathrm{~kg} / \mathrm{m}^{3} ;$ sound wave propagation speed $c=335 \mathrm{~m} / \mathrm{s}$; sound damping factor of the air $\mu=0$; density 
of the partition wall $\rho=650 \mathrm{~kg} / \mathrm{m}^{3}$; elasticity modulus $E=29.5 \mathrm{e}+9 \mathrm{~Pa}$; sound propagation speed in the partition wall material $c_{p}=6,790 \mathrm{~m} / \mathrm{s}$; sound damping factor of the partition wall $\mu=0.29$. The results of the theoretical experiment are presented below (Figs. 1-5).

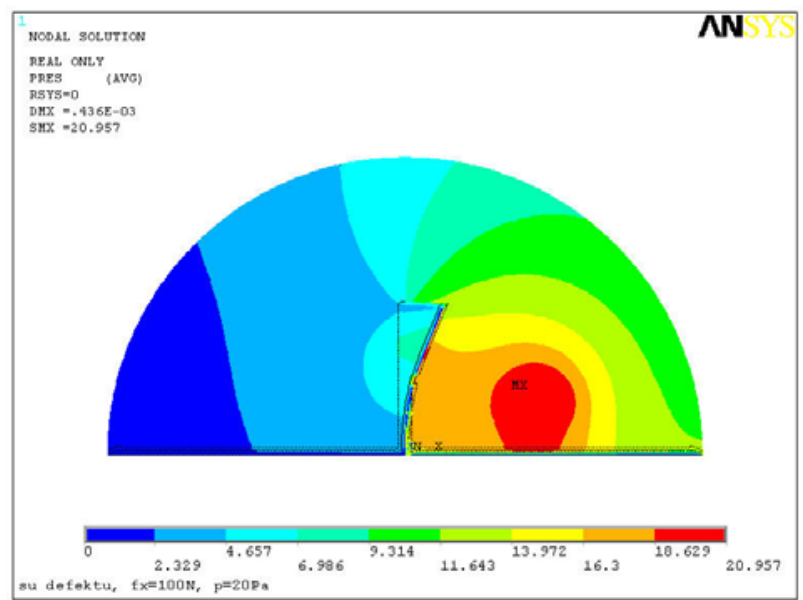

Fig. 1 Acoustic field of the partition wall with the defect applying harmonic sound source spot excitation $p=20 \mathrm{~Pa}$ and concentrated force $F=100 \mathrm{~N}$ simultaneously with the resonance frequency

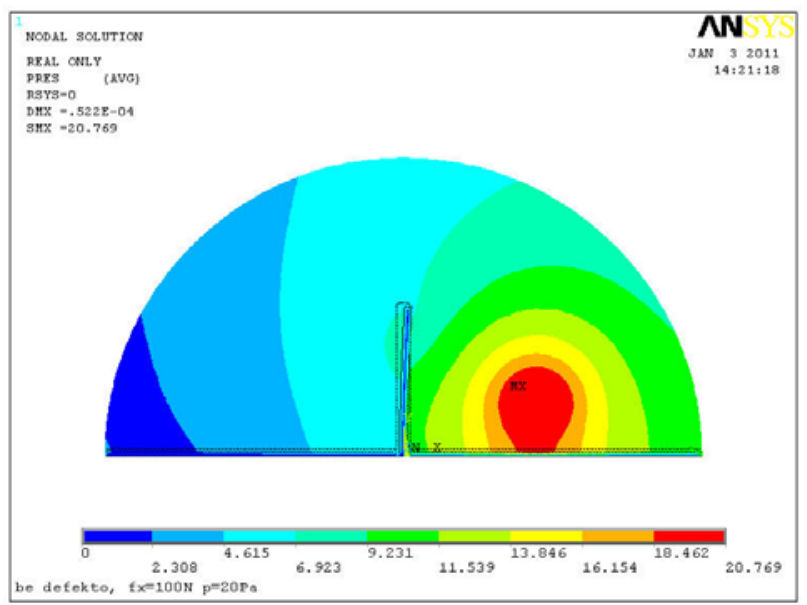

Fig. 2 Acoustic field of the partition wall without the defect applying harmonic sound source spot excitation $p=20 \mathrm{~Pa}$ and concentrated force $F=100 \mathrm{~N}$ simultaneously with the resonance frequency

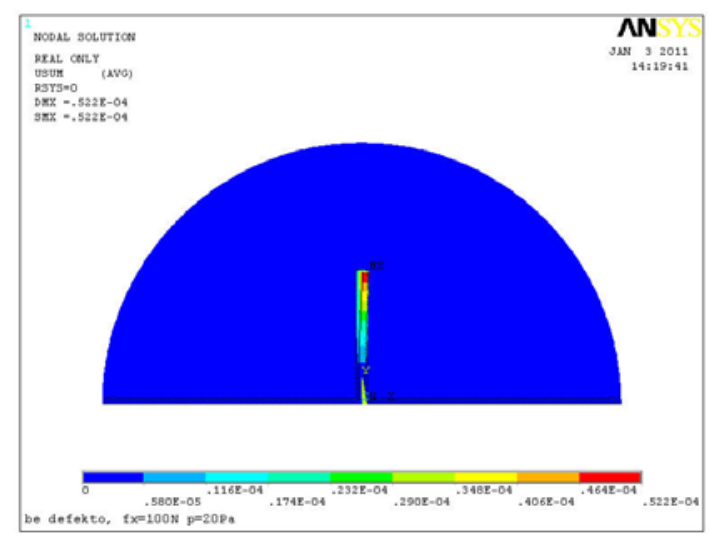

Fig. 3 Deformation of the partition wall without the defect applying harmonic sound source spot excitation $p=20 \mathrm{~Pa}$ and concentrated force $F=100 \mathrm{~N}$ simultaneously with the resonance frequency

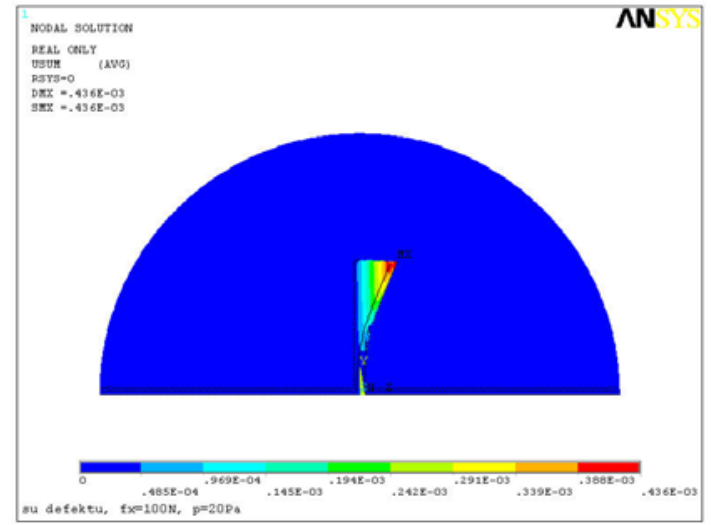

Fig. 4 Deformation of the partition wall with the defect applying harmonic sound source spot excitation $p=20 \mathrm{~Pa}$ and concentrated force $F=100 \mathrm{~N}$ simultaneously with the resonance frequency

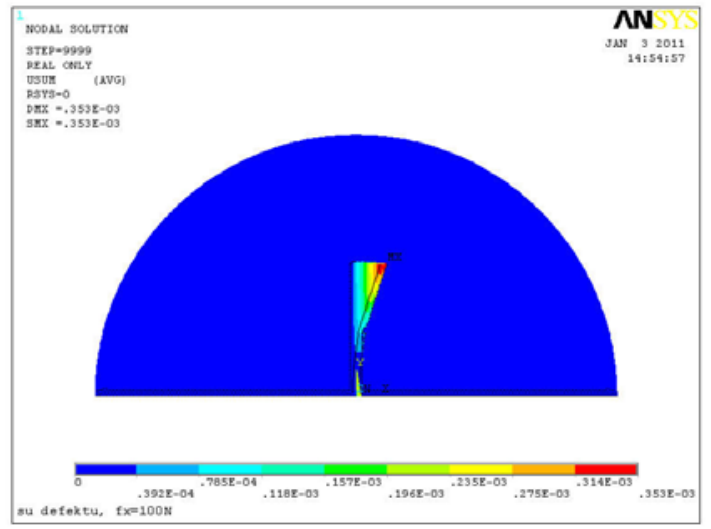

Fig. 5 Deformation of the partition wall with the defect applying harmonic concentrated force $F=100 \mathrm{~N}$ with the resonance frequency

The results show that under harmonic excitation, the changed condition of the partition wall changes the acoustic field. If the partition wall is with defect, max sound pressure values are at the top part of the partition wall and not at the source area as it is in case of the partition wall without defect. What concerns deformations of the partition wall, we see that acoustic load increase deformations. In case of the partition wall with defect, deformation increases by $10 \%$ compared to the partition wall without defect.

\subsection{Interaction between floor-column and acoustic field 3D model}

The investigated three dimensional model consisted of acoustic and structural mediums. FLUID30 and SOLID45 elements have been used for the modelling. Harmonic analysis has been performed during modelling. During this analysis, the system has been excited applying harmonic sound pressure of particular magnitude. Condition of the structure has been altered during analysis, i.e., a structure made from concrete without defect and with defect has been modelled. The defect has been modelled changing floor material elasticity modulus. The value of the elasticity module was diminished by $30 \%$ for the second floor in a width of $0.6 \mathrm{~m}$ along its symmetry axis across whole thickness. The distance between excitation source and the partition wall was $1 \mathrm{~m}$. Physical properties 


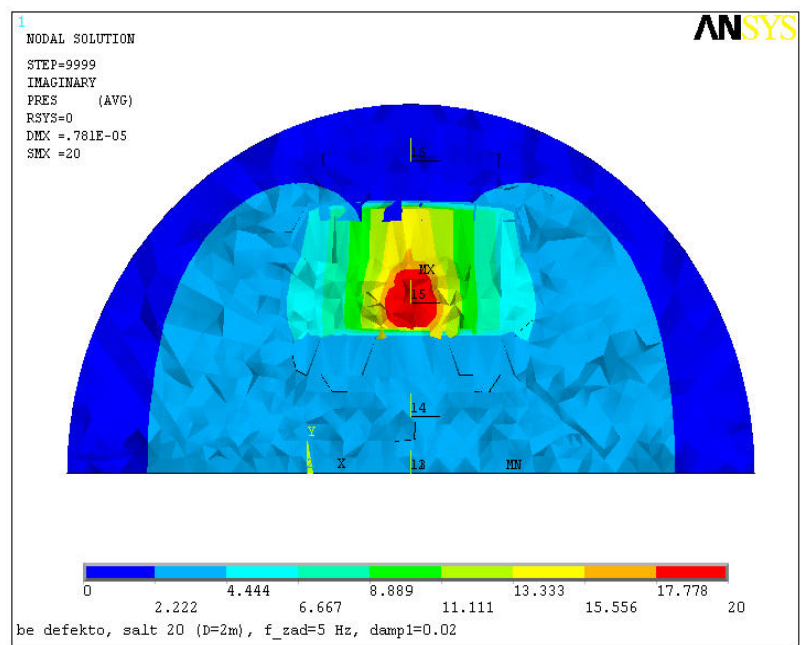

Fig. 6 Acoustic field at the structure environment applying harmonic sound pressure excitation $p=20 \mathrm{~Pa}$ with the resonance frequency

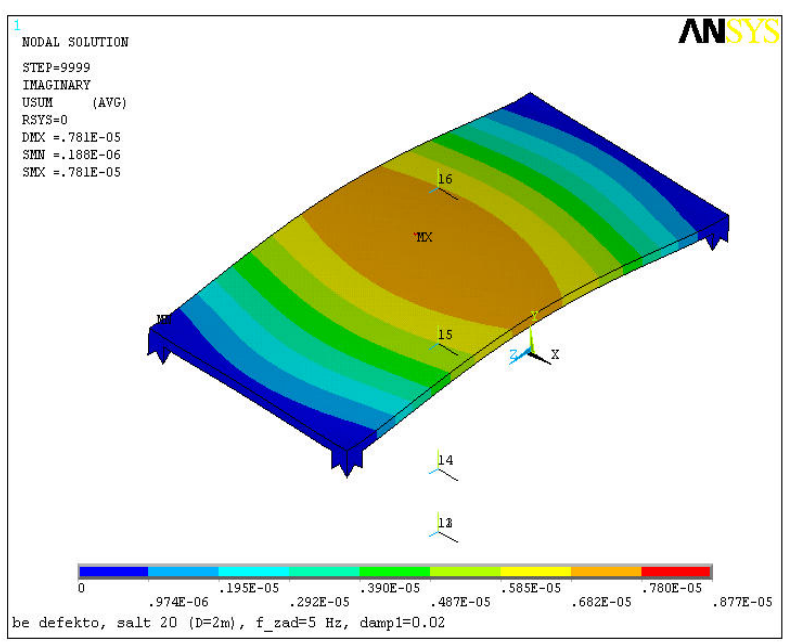

Fig. 7 Deformations of the floor without defect, applying harmonic sound pressure excitation $p=20 \mathrm{~Pa}$ with the resonance frequency

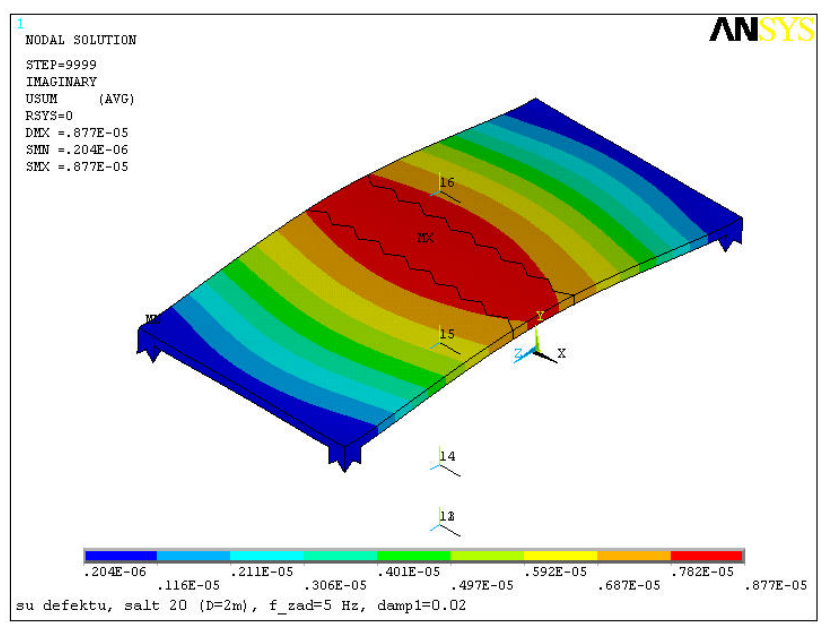

Fig. 8 Deformations of the floor with defect, applying harmonic sound pressure excitation $p=20 \mathrm{~Pa}$ with the resonance frequency

of the model components were the following: air density $\rho=1.2 \mathrm{~kg} / \mathrm{m}^{3}$; sound wave propagation speed $c=335 \mathrm{~m} / \mathrm{s}$; sound damping factor of the air $\mu=0$; density of the floors and columns $\rho=2.400 \mathrm{~kg} / \mathrm{m}^{3}$; elasticity modulus $E=20.7 \mathrm{e}+9 \mathrm{~Pa}$; sound propagation speed in the structure material $c_{p}=2.960 \mathrm{~m} / \mathrm{s}$; sound damping factor of the partition wall $\mu=0.01$. The results of the theoretical experiment are presented below (Figs. $6-8$ ).

The results show that acoustic excitation has influence on the structure deformation state. We see that acoustic load of the same magnitude and frequency (using harmonic excitation) can trigger heavier deformations of the structure with defect. Deformations under acoustic load increase by $12 \%$ compared to the structure without defect.

\section{Conclusion}

The results of the research presented here have theoretical and practical importance. Theoretical models reveal the effects of nonhomogeneous structures acoustic field formation, and in practice - these results can be used to identify the condition of mechanical system (in this case - nonhomogeneous structure) more accurately using diagnostic algorithms, for example, during automated monitoring of the buildings condition with increased noise pressure bursts (such as sports arenas).

\section{References}

1. Kudzys, A.; Lukoševičienė, O. 2009. On the safety prediction of deteriorating structures, Mechanika 4(78): 5-11.

2. Samofalov, M.; Šlivinskas, T. 2009. Stability analysis of steel frames with variable cross-section for sports and entertainment centre, Mechanika 5(79): 5-12.

3. Vobolis, J.; Albrektas, D. 2010. Study of resonance phenomena in acoustic wood boards, Vibroengineering 4(12): 514-522.

4. Kliučininkas, L.; Šaliūnas D. 2006. Noise mapping for the management of urban traffic flows, Mechanika 3(59): 61-66.

5. Doroševas, V.; Volkovas, V. 2009. Investigation of adequacy of the analytical model of sound field in rectangular room, Mechanika 6(80): 52-55.

6. Doroševas, V. 2010. The analytical method of acoustic field estimation in the cylindrical shape, Vibroengineering 4(12): 589-592.

7. Mikalauskas, R.; Volkovas, V. 2007. Development of the theoretical model of acoustic field on the basis of FEM and analysis of effectiveness, Ultragarsas 62(4): 32-35.

8. Mikalauskas, R.; Volkovas, V. 2009. Modelling of sound propagation in the closed space and its interaction with obstacles, Mechanika 6(80): 42-47.

9. Požèra, A.; Volkovas, V. 2009. Investigation of possible minimization of number of measurement points in $2 \mathrm{D}$ acoustic field reconstruction, Ultragarsas 64(1): 7-10.

10. Mikalauskas, R.; Volkovas, V. 2008. Investigation and application of theoretical acoustic field model evaluating the change of environmental conditions, Proceedings of the Int. Conf. ACOUSTICS `08, Paris, June 29 - July 4: 2067-2071. 


\section{Acknowledgement}

This research was funded by a grant (No. MIP71/2010) from the Research Council of Lithuania.

R. Mikalauskas, V. Volkovas

\section{AKUSTINIO LAUKO IR HETEROGENINIŲ PASTATŲ STRUKTŪRŲ SĄVEIKOS TYRIMAS}

\section{R e z i u m è}

Darbe nagrinejjami du akustinio lauko ir statinio konstrukcijos sąveikos modeliai. Pirmajame - dvimačiame modelyje nagrinejjama akustinès terpès ir pertvaros sąvei$\mathrm{ka}$, esant skirtingoms pertvaros būklèms. Antrajame - trimačiame modelyje nagrinejjama dviejų aukštų perdanga kolonos konstrukcijos elgsena žadinant mechaniškai ir akustine apkrova, esant skirtingam konstrukcijos nehomogeniškumo laipsniui. Šiuo atveju buvo modeliuojamas galimas mechaninès sistemos standumo lenkiant sumažejjimas. Gauti rezultatai parodè, jog to paties dydžio ir dažnio akustinè apkrova, esant harmoniniam žadinimui, gali sukelti didesnes defektą turinčios konstrukcijos deformacijas.

\section{R. Mikalauskas, V. Volkovas}

\section{INVESTIGATION OF INTERACTION BETWEEN ACOUSTIC FIELD AND NONHOMOGENEOUS BUILDING STRUCTURES}

\section{S u m m a r y}

Two models of interaction between acoustic field and building structure are investigated. The first - two dimensional model, where interaction between partition wall and acoustic medium has been modelled (given different conditions of the partition wall). The second - three dimensional model, which is used to analyze two storey floor-columns structure, applying acoustic and mechanical excitation, and different nonhomogeneity degrees of the structure. Possible mechanical system defect (reduction of rigidity due to floor flaw) has been modelled during the latter.The results showed that the same size and frequency of the acoustic load at harmonic excitation may lead to higher deformation of the structure having a defect.

Р. Микалаускас, Б. Волковас

\section{ИССЛЕДОВАНИЕ ВЗАИМОДЕЙСТВИЯ АКУСТИЧЕСКОГО ПОЛЯ С НЕОДНОРОДНОЙ КОНСТРУКЦИЕЙ ЗДАНИЯ}

P е 3 ю м е

Исследуются две модели взаимодействия акустического поля и конструкции здания. Первая модель двумерная. Моделируется взаимосвязь акустической среды и перегородки при различных условиях (изменении технического состояния перегородки). Вторая модель трехмерная. Исследовалась двухэтажная структура из перекрытий и колон при механическом и акустическом нагружениях и различной степени неоднородности. Моделировалось возможное уменьшение изгибной жесткости. Полученные результаты показали, что одинаковые по величине и частоте нагрузки в виде гармонического акустического поля приводят к большему деформированию перегородок с дефектами чем без дефектов.

Received December 21, 2010 Accepted June 07, 2011 